\title{
Pengaruh Strategi Promosi terhadap Keputusan Konsumen dalam Pembelian Kosmetik Sari Ayu di Outlet Mall Palembang Icon
}

\author{
Nadya Annisa ${ }^{1)}$, Roswaty ${ }^{2)}$, Budi Setiawan ${ }^{3)}$ \\ 1), 2, 3) Universitas Indo Global Mandiri, Palembang, Indonesia \\ Email: nadyaannisa1999@gmail.com ${ }^{l}$
}

\begin{abstract}
Abstrak
Penelitian ini bertujuan untuk melihat pengaruh strategi promosi terhadap keputusan konsumen dalam pembelian kosmetik Sari Ayu di outlet Mall Palembang Icon atau bisa juga disebut dengan PT. Martina Berto Tbk yang bertepatan di jalan POM IX. Penelitian ini merupakan penelitian deskriptif kuantitatif dengan jumlah sampel sebanyak 70 responden, sedangkan teknik pengambilan sampel yang digunakan dalam penelitian ini adalah sampling kebetulan (Accidental). Pada penelitian ini variabel bebasnya terdiri dari Strategi Promosi, sedangkan variabel terikatnya adalah keputusan pembelian. Pengujian instrumen menggunakan uji validitas dan reliabilitas. Sedangkan metode analisis data menggunakan analisis regresi linier sederhana dengan uji $t, R$, dan $R^{2}$. Hasil perhitungan uji t sebesar thitung X (Strategi Promosi) sebesar 10,679 pada tingkat sig 0,000. Hasil uji koefisien Korelasi $(R)$ diperoleh nilai sebesar 0,791 menunjukan bahwa hubungan antara variabel X (Strategi Promosi) mempunyai hubungan yang kuat terhadap variabel $Y$ (keputusan pembelian). Hasil uji koefisien determinasi $\left(R^{2}\right)$ menunjukan Adjusted $R$ Square 0,626 atau 62,6\%. Hasil perhitungan uji regresi linier sederhana sebesar $Y=-$ 0,922-1,007X. Hasil dari penelitian ini mengatakan bahwa Strategi Promosi memiliki pengaruh positif terhadap keputusan pembelian.
\end{abstract}

Kata Kunci: strategi promosi, keputusan pembelian, pemasaran, perilaku konsumen

\begin{abstract}
This study aims to see the effect of promotional strategies on consumer decisions in purchasing Sari Ayu cosmetics at the Palembang Icon Mall outlet or also known as PT. Martina Berto Tbk which coincides on Jalan POM IX. This research is a quantitative descriptive study with a total sample of 70 respondents, while the sampling technique used in this study is accidental sampling. In this study, the independent variable consists of the Promotion Strategy, while the dependent variable is the purchase decision. Testing instruments using validity and reliability tests. While the data analysis method uses simple linear regression analysis with $\mathrm{t}, \mathrm{R}$, and $\mathrm{R} 2$ tests. The result of $t$ test calculation is $t$ count $X$ (Promotion Strategy) of 10.679 at the sig 0.000 level. The results of the correlation coefficient test $(\mathrm{R})$ obtained a value of 0.791 , indicating that the relationship between variable $\mathrm{X}$ (Promotion Strategy) has a strong relationship with variable Y (purchase decision). The test results of the coefficient of determination (R2) show Adjusted R Square 0.626 or $62.6 \%$. The calculation result of simple linear regression test is $\mathrm{Y}=-0,922-1,007 \mathrm{X}$. The results of this study indicate that the Promotion Strategy has a positive influence on purchasing decisions.
\end{abstract}

Keywords: promotion strategy, purchasing decisions, marketing, consumer behavior

\section{Pendahuluan}

Manajemen pemasaran merupakan sebuah rangkaian proses analisis, perencanaan, pelaksanaan, serta pengawasan dan pengendalian suatu kegiatan pemasaran yang memiliki tujuan untuk mencapai target suatu perusahaan secara efektif dan efisien. Menurut Assauri (2004) manajemen pemasaran merupakan kegiatan analisis, perencanaan, pelaksanaan, dan pengendalian berbagai program yang disusun dalam pembentukan, pembangunan dan pemeliharaan laba hasil dari transaksi atau pertukaran melalui sasaran pasar untuk mencapai tujuan perusahaan dalam jangka panjang. Strategi promosi merupakan langkah yang harus 
diperhitungkan dalam rangkaian aktivitas manajemen pemasaran. Kegiatan pada strategi promosi merupakan langkah di bidang pemasaran berupa interaksi atau komunikasi yang dijalankan perusahaan dengan konsumen atau pelanggan.

Menurut Swastha dan Irawan (2008) promosi merupakan arus informasi atau persuasi satu arah yang dibuat untuk mengerahkan seseorang atau organisasi kepada tindakan menciptakan pertukaran dalam pemasaran. Dapat dilihat bahwa strategi promosi merupakan kegiatan yang direncanakan dengan maksud membujuk konsumen agar mau membeli produk perusahaan sehingga tujuan untuk meningkatkan penjualan diharapkan dapat tercapai. Dengan adanya persaingan yang cukup kompetitif saat ini menyebabkan makin diperlukannya informasi pemasaran. Informasi tersebut diperlukan untuk mengantisipasi perubahan informasi mengenai selera konsumen terhadap suatu produk yang ditawarkan.

Selain produk, harga juga merupakan suatu hal yang penting atas suatu produk, karena akan berpengaruh terhadap keuntungan produsen. Harga menjadi pertimbangan khusus bagi para konsumen dan produsen. Harga merupakan salah satu penentu keberhasilan suatu perusahaan karena harga menentukan seberapa besar keuntungan yang akan diperoleh perusahaan dari penjualan produknya baik berupa barang maupun jasa. Menetapkan harga terlalu tinggi akan menyebabkan penjualan akan menurun, namun jika harga terlalu rendah akan mengurangi keuntungan yang dapat diperoleh.

Harga merupakan nilai tukar yang bisa disamakan dengan uang atau barang lain untuk dimanfaatkan yang diperoleh dari suatu barang atau jasa bagi seseorang atau kelmpok pada waktu tertentu dan tempat tertentu. Menurut Ramli (2013) harga merupakan nilai relatif yang dimiliki oleh suatu produk. Nilai tersebut bukanlah indikator pasti yang menunjukkan besarnya sumber daya yang dibutuhkan untuk menghasilkan produk. Berdasarkan beberapa pengertian harga di atas maka dapat disimpulkan bahwa harga merupakan keseluruhan nilai suatu barang maupun jasa yang diberikan dalam bentuk uang.

Produk dan harga sangat mempengaruhi keputusan konsumen untuk membeli sesuatu yang di pasarkan oleh suatu perusahaan. Keputusan pembelian konsumen merupakan proses yang terjadi pada konsumen ketika ia memutuskan untuk membeli suatu produk. Menurut Kotler (2002) keputusan pembelian adalah tindakan dari konsumen untuk mau membeli atau tidak terhadap suatu produk yang dipasarkan. Dari berbagai faktor yang mempengaruhi konsumen dalam melakukan pembelian suatu produk atau jasa, biasanya konsumen selalu mempertimbangkan kualitas, harga dan produk yang sudah dikenali oleh masyarakat.

Berdasarkan latar belakang di atas, maka rumusan pada penelitian ini adalah: Bagaimana pengaruh Strategi Promosi terhadap keputusan konsumen dalam pembelian kosmetik Sari Ayu di Outlet Mall Palembang Icon? Adapun hipotesis yang akan dijadikan acuan dalam memecahkan pokok permasalahan adalah: Diduga Strategi Promosi mempunyai pengaruh yang signifikan terhadap keputusan pembelian kosmetik Sari Ayu di Outlet Mall Palembang Icon.

\section{Tinjauan Pustaka}

\subsection{Strategi Promosi}

Strategi promosi dan pemasaran merupakan merupakan bagian penting dalam sebuah bisnis (Susanti, Halin, \& Kurniawan, 2018). Karena promosi bukan hanya cara berkomunikasi dengan calon konsumen (Wadud, 2018). Namun juga melalui kegiatan promosi ini anda akan mempengaruhi dan membujuk calon konsumen untuk membeli produk maupun jasa yang ditawarkan (Marnisah, Saputra, \& Azra'ie, 2016). Menurut Moekijat (2000) strategi promosi 
merupakan kegiatan perusahaan untuk mendorong penjualan dengan mengarahkan komunikasi-komunikasi yang meyakinkan kepada para pembeli. Sedangkan menurut Lamb et al. (2001) strategi promosi adalah rencana untuk penggunaan yang optimal dari elemen-elemen promosi yaitu periklanan, hubungan masyarakat, penjualan pribadi dan promosi penjualan. Selanjutnya, menurut Wahid \& Wadud (2020), salah satu strategi promosi yang efektif di era digital adalah dengan implementasi melalui media sosial.

\subsection{Indikator Strategi Promosi}

a. Produk

Secara umum definisi produk merupakan hasil jadi dari sebuah proses yang dilakukan oleh pembuat atau produsen yang kemudian akan didistribusikan kepada pembeli atau konsumen sesuai yang dibutuhkannya. Dalam kehidupan sehari-hari sebagian masyarakat juga akan memilih dan membeli produk yang harganya relatif murah dan bisa dijangkau sesuai dengan kemampuan. Dalam hal ini tentu pilihan produk-produk yang menyebar dimasyarakat luas sangatlah bayak dan sebagian besar diantaranya merupakan produkproduk yang rill.

Menurut pembahasan diatas, dapat disumpulkan bahwa Produk merupakan segala sesuatu yang dapat ditawarkan produsen untuk diperhatikan, diminta, dicari, dibeli, digunakan, atau dikonsumsi pasar sebagai pemenuh kebutuhan atau keinginan pasar yang bersangkutan. Menurut Tjiptono (2002) secara konseptual produk adalah pemahaman subyektif dari produsen atas sesuatu yang bisa ditawarkan, sebagai usaha untuk mencapai tujuan organisasi melalui pemenuh kebutuhan dan keinginan konsumen, sesuai dengan kompetensi dan kapasitas organisasi serta daya beli pasar.

b. Harga

Dalam proses jual beli harga merupakan salah satu hal yang penting, karena harga adalah alat tukar dalam transaksi. Harga merupakan satu-satunya unsur bauran pemasaran yang bersifat fleksibel dimana setiap saat dapat berubah-ubah. Harga juga merupakan salah satu faktor persaingan dalam memasarkan produk. Penggunaan istilah harga umumnya dipakai dalam kegiatan jual-beli suatu produk, baik itu barang maupun jasa.

\subsection{Keputusan Pembelian Konsumen}

Keputusan pembelian konsumen merupakan sebuah tindakan yang dilakukan konsumen untuk membeli suatu produk (Arifai \& Trihandayani, 2018; Batu, Suryani, Septia, \& Sekaryahya, 2020). Setiap produsen mempunyai strategi agar konsumen memutuskan untuk membeli produknya (Irawan, Marnisah, \& Azrai'e, 2018). Menurut Kotler (2002) keputusan pembelian adalah tindakan dari konsumen untuk mau membeli atau tidak terhadap suatu produk. Dari berbagai faktor yang mempengaruhi konsumen dalam melakukan pembelian suatu produk atau jasa, biasanya konsumen selalu mempertimbangkan kualitas, harga dan produk sudah dikenal oleh masyarakat.

Menurut Nitisusastro dan Mulyadi (2012) pengambilan keputusan pembelian konsumen merupakan proses interaksi antara sikap afektif, sikap kognitif, sikap behavioral dengan faktor lingkungan dengan mana manusia melakukan pertukaran dalam semua aspek kehidupannya. Sikap kognitif merefleksikan sikap pemahaman, sikap afektif merefleksikan sikap keyakinan dan sikap behavioral merefleksikan sikap tindak nyata. Keputusan membeli atau tidak membeli merupakan bagian dari unsur yang melekat pada diri individu konsumen yang disebut behavior 
dimana ia merujuk kepada tindakan fisik yang nyata dapat dilihat dan dapat diukur oleh orang lain.

\subsection{Jenis - Jenis Perilaku Keputusan Konsumen}

Ada beberapa jenis perilaku konsumen saat hendak mengambil keputusan, yaitu:

a. Perilaku Pembelian Kompleks, konsumen melakukan hal tersebut ketika mereka sangat terlibat dalam pembelian dan merasa ada perbedaan yang signifikan antar merek. Konsumen mungkin sangat terlibat ketika produk itu mahal, beresiko, jarang dibeli dan sangat memperlihatkan ekspresi diri. Umumnya, konsumen harus mempelajari banyak hal tentang kategori produk.

b. Perilaku Pembelian Pengurangan Disonansi, perilaku pembelian pengurangan disonasi terjadi ketika konsumen sangat terlibat dalam pembelian yang mahal, jarang dilakukan atau beresiko. Tetapi hanya melihat sedikit perbedaan antar merek.

c. Perilaku Pembelian Kebiasaan, perilaku ini terjadi dalam keadaan keterlibatan konsumen yang rendah dan sedikit perbedaan merek.

- Perilaku Pembelian Mencari Keragaman, konsumen melakukan hal tersebut dalam situasi yang mempunyai karakter keterlibatan konsumen rendah tetapi anggapan perbedaan merek yang signifikan. Dalam kasus semacam itu, konsumen sering melakukan banyak pertukaran merek.

\subsection{Indikator Keputusan Pembelian}

Menurut Akbar (2011) indicator keputusan pembelian adalah :

a. Yakin dalam membeli, setelah konsumen memilih beberapa alternatif dan mengerucutkan pada beberapa pilihan, dia akan tambah mantap setelah mendengar penjelasan yang baik dari penjual dan memutuskan untuk membeli.

b. Mencari Informasi, seorang konsumen akan mencari informasi sebanyak-banyaknya tentang produk yang akan dibelinya. Konsumen akan mencari tahu informasi suatu produk tentang fitur-fiturnya, harga, penjualannya dan juga jaminan dari perusahaan.

c. Merencanakan Pembelian, seorang konsumen tahu bahwa ada kebutuhan yang perlu dipenuhi. Sehingga konsumen pasti akan merencanakan pembelian terhadap produk yang mereka butuhkan, sehingga jika ada kesempatan yang dapat dilakukan dia akan membeli barang tertentu tersebut bila tersedia di pasar.

d. Sesuai Keinginan, konsumen akan membeli produk yang sesuai keinginan mereka sehingga konsumen tersebut akan merasa puas atas hasil pembelian yang telah dilakukan dan setiap konsumen akan berbeda keinginannya.

\section{Metodologi}

Penelitian ini akan dilakukan di Outlet Mall Sari Ayu Palembang Icon, yang bertempatan di Jalan POM IX Lorong Pakjo, Kecamatan Ilir Barat I Kota Palembang Sumatera Selatan 30137. Responden yang dijadikan sampel adalah pelanggan kosmetik Sari Ayu. Populasi penelitian ini adalah pelanggan kosmetik Sari Ayu yang berjumlah 235 yang membeli produk kepada PT. Martina Berto. Dari jumlah 235 populasi pelanggan kosmetik Sari Ayu disederhakan menggunakan rumus Slovin sehingga sampel menjadi 70 pelanggan kosmetik Sari Ayu.

Adapun analisis data yang dipakai, yaitu: 


\section{Uji Validitas}

Digunakan untuk mengukur sah (valid) atau tidaknya suatu kuesioner. Suatu kuesioner dikatakan valid jika pertanyaan pada kuesioner mampu untuk mengungkap suatu yang akan diukur oleh kuesioner tersebut. Menurut Ghozali (2009) uji validitas digunakan untuk mengukur sah, atau valid tidaknya suatu kesioner. Suatu kuesioner dikatakan valid jika pertanyaan pada kuesioner mampu untuk mengungkapkan susuatu yang akan diukur oleh kuesioner tersebut. Uji validitas dihitung dengan membandingkan nilai $\mathrm{r}$ hitung (correlated item-total correlation) dengan nilai $r$ tabel, jika $r$ dihitung $>r$ tabel dan nilai positif maka butir atau pertanyaan tersebut dinyatakan valid.

2. Uji Reliabilitas

Reliabilitas digunakan untuk mengukur konsistensi dari serangkaian pengukur atau serangkaian alat ukur. Menurut Ghozali (2009) uji reliabilitas merupakan alat ukur untuk mengukur suatu kuesioner yang merupakan indikator dari peubah atau konstruk. Reliabilitas suatu test merujuk pada derajat stabilias, konsistensi, daya prediksi dan akurasi. Pengukuran yang memiliki reliabilitas yang tinggi adalah pengukuran yang dapat menghasilkan data yang reliable. Uji reliabilitas dapat diukur secara bersama sama terhadap seluruh butir pertanyaan jika nilai Alpha $>0,06$ makanilai reliable.

3. Uji Normalitas

Uji Normalitas bertujuan untuk menguji apakah dalam model regresi, variabel pengganggu atau residual memiliki distribusi normal. Uji normalitas diperlukan untuk melakukan pengujian-pengujian variabel lainnya dengan mengasumsikan bahwa nilai residual mengikuti distribusi normal. Seperti diketahui uji t mengasumsikan bahwa nilai residual mengikuti distribusi normal. Kalau asumsi ini dilanggar maka uji statistik menjadi tidak valid (Ghozali:2013).

\section{Regresi Linier Sederhana}

Tujuan dari teknik analisis Regresi adalah untuk memprediksi bagaimana perubahan nilai yang terjadi pada variabel $\mathrm{X}$ dan variabel $\mathrm{Y}$ dimanipulasi (dinaikkan atau diturunkan nilainnya). Penelitian ini menggunakan analisis regresi linier sederhana. Menurut Sujarweni (2014) menjelaskan bahwa regresi liner sederhana merupakan regresi yang memiliki satu variable dependen dan satu variable idependen.

5. Koefisien Korelasi (R)

Koefisien korelasi juga dikenal sebagai nilai hubungan atau korelasi antara dua atau lebih variabel yang diteliti. Nilai koefisien korelasi sebagaimana juga tarif signifikasi digunakan sebagai pedoman untuk menentukan hipotesis dapat juga diterima atau ditolak. Nilai koefisien bergerak dari $0 \geq 1$ atau $1 \leq 0$.

6. Koefisien Determinasi $\left(\mathrm{R}^{2}\right)$

Mengukur seberapa besar kemampuan model dalam menerangkan variabel terikat. Jika $\mathrm{R}^{2}$ semakin besar nilainya (mendekati satu) maka dapat dikatakan bahwa pengaruh variabel bebas, yaitu Strategi Promosi (X) adalah kuat terhadap variabel terikat, yaitu Keputusan Pembelian (Y). hal ini berarti model yang digunakan semakin kuat untuk menerangkan pengaruh variabel bebas yang diteliti terhadap variabel terikat. 


\section{Uji t}

Untuk menguji kebenaran hipotesis yang digunakan dalam penelitian ini pengujian dilakukan menggunakan uji t. Uji t pada dasarnya menunjukkan seberapa jauh pengaruh suatu variabel independen secara individual dalam menerangkan variasi variabel dependen. Pengambilan keputusan ini dilakukan berdasarkan perbandingan nilai signifikan yang telah ditetapkan yaitu sebesar 5\% $(a=0,05)$.

\section{Hasil dan Pembahasan}

Berdasarkan kuesioner yang dibagikan kepada responden, berikut ini akan dilakukan pembahasan yang bertujuan untuk membahas masalah penelitian dan menjawab tujuan penelitian. Responden merupakan pelanggan kosmetik Sari Ayu di Outelt Mall Palembang Icon, studi kasus PT. Martina Berto Tbk dimana dari sejumlah kuesioner telah disebutkan 70 responden berdasarkan rumus slovin di bab sebelumnya, pengolahan data menggunakan SPSS v.23 for windows.

\subsection{Uji Regresi Linear Sederhana}

Tujuan dari teknik analisis regresi adalah untuk memprediksi bagaimana perubahan nilai yang terjadi pada variabel $\mathrm{X}$ dan variabel $\mathrm{Y}$ yang dimanipulasi (dinaikkan atau diturunkan nilainya). Penelitian ini menggunakan analisis regresi linier sederhana.

Menurut Sujarweni (2014) menjelaskan bahwa regresi linier sederhana merupakan regresi yang dimiliki suatu variabel dependen dan suatu variabel independen. Model pemasaran regresi linier sederhana dengan menggunakan rumus sebagai berikut:

$\mathbf{Y}=\mathbf{a}+\mathbf{b X}$

Keterangan:

$\mathrm{Y} \quad=$ Variabel dependen, yaitu keputusan pambelian

a $\quad=$ Konstanta, yaitu titik potong kurva tehadap sumbu $\mathrm{Y}$

$\mathrm{b} \quad=$ Koefisien regresi, yaitu kemiringan kurva linear

$\mathrm{X}=$ Variabel independen, yaitu strategi promosi

Tabel 1. Hasil Uji Regresi Linier Sederhana

\begin{tabular}{|c|c|c|c|c|c|c|c|}
\hline \multirow{2}{*}{\multicolumn{2}{|c|}{ Model }} & & \multicolumn{2}{|c|}{$\begin{array}{l}\text { Unstandardized } \\
\text { Coefficients }\end{array}$} & \multirow{2}{*}{\begin{tabular}{|l}
$\begin{array}{l}\text { Standardized } \\
\text { Coefficients }\end{array}$ \\
Beta
\end{tabular}} & \multirow[b]{2}{*}{$\mathrm{T}$} & \multirow[b]{2}{*}{ Sig. } \\
\hline & & & B & Std. Error & & & \\
\hline \multirow[t]{2}{*}{1} & (Constant) & & -.922 & 3.436 & & -.268 & .789 \\
\hline & $\begin{array}{l}\text { Total } \\
\text { Promosi }\end{array}$ & Strategi & $\mathrm{i} \mid 1.007$ & .094 & .791 & 10.679 & .000 \\
\hline
\end{tabular}

a. Dependent Variable: Total Keputusan Pembelian 
Persamaan regresi tersebut jika dimasukkan ke dalam persamaan regresi $\mathrm{Y}=\mathrm{a}+\mathrm{bX}$ dapat dijelaskan sebagai berikut: Konstanta sebesar -0.922 yang artinya jika strategi promosi (X) nilainya adalah 0 , maka keputusan pembelian $(\mathrm{Y})$ nilainya negatif yaitu sebesar -0.922 .

Koefisien regresi variabel $\mathrm{X}$ sebesar 1.007 yang artinya jika strategi promosi mengalami kenaikan 1, maka keputusan pembelian (Y) akan mengalami peningkatan sebesar 1.007. Koefisien bernilai positif artinya terjadi hubungan positif antara strategi promosi dengan keputusan pembelian.

\subsection{Uji Koefisien Korelasi (R)}

Koefisien korelasi adalah nilai yang menunjukkan kuat atau tidaknya hubungan linier antar dua variabel. Koefisien korelasi biasa dilambangkan dengan huruf $r$ dimana nilai $r$ dapat bervariasi dari -1 sampai +1 . Nilai $r$ yang mendekati -1 atau +1 menunjukkan hubungan yang kuat antara dua variabel tersebut, nilai r yang mendekati 0 mengindikasikan lemahnya hubungan antara dua variabel tersebut. Sedangkan tanda positif dan negatif memberikan informasi mengenai arah hubungan antara dua variabel tersebut. Jika bernilai + (positif) maka kedua variabel tersebut memiliki hubungan yang searah. Dalam arti lain peningkatan $\mathrm{X}$ akan bersama dengan peningkatan Y dan begitu juga sebaliknya. Jika bernilai (negatif) artinya korelasi antara kedua variabel tersebut bersifat berlawanan peningkatan nilai $\mathrm{X}$ akan disertakan dengan penurunan $\mathrm{Y}$.

Tabel 2. Koefisien Korelasi (R)

\begin{tabular}{|l|l|l|l|l|}
\hline Model & $\mathrm{R}$ & R Square & Adjusted R Square & $\begin{array}{l}\text { Std. Error of the } \\
\text { Estimate }\end{array}$ \\
\hline 1 & $.791^{\mathrm{a}}$ & .626 & .621 & 1.780 \\
\hline
\end{tabular}

a. Predictors: (Constant), Total Strategi Promosi

Dari tabel di atas diketahui bahwa responden sebanyak 70 dihasilkan nilai korelasi sebesar 0.791 untuk melakukan interpretasi kekuatan hubungan antara dua variabel dilakukan dengan melihat angka koefisien korelasi dari hasil perhitungan dengan menggunakan interpretasi nilai r (Sugiyono 2014:250). Dari data diatas diambil kesimpulan bahwa antara variabel strategi promosi terhadap keputusan pembelian, mempunyai hubungan yang kuat karena memiliki nilai korelasi sebesar $0.791(79,1 \%)$.

\subsection{Uji Determinasi $\left(R^{2}\right)$}

Nilai $\mathrm{R}^{2}$ digunakan untuk mengukur seberapa jauh kemampuan model dalam menerangkan variasi variabel dependen. Tetapi $\mathrm{R}^{2}$ mengandung kelemahan mendasar dimana adanya bias terhadap jumlah variabel independen yang dimasukkan dalam model. Oleh karena itu, pada penelitian ini yang digunakan adalah adjusted $\mathrm{R}^{2}$ berkisar nol dan satu. Nilai adjusted $\mathrm{R}^{2}$ dapat naik atau turun apabila suatu variabel independen ditambahkan ke dalam model.

Nilai adjusted $\mathrm{R}^{2}$ yang kecil berarti kemampuan variabel-variabel independen dalam menjelaskan variasi variabel dependen memberikan hampir semua informasi yang dibutuhkan untuk memprediksi variabel dependen (Ghozali:2012,83). Dimana model linier berganda ini, akan dilihat besarnya kontribusi untuk variabel bebas secara bersama-sama terhadap variabel terikat dengan melihat besarnya koefisien determinasi totalnya $\left(\mathrm{R}^{2}\right)$. Jika $\left(\mathrm{R}^{2}\right)$ yang diperoleh 
mendekati 1 (satu) maka dapat dikatakan semakin kuat model tersebut menerangkan hubungan variabel bebas terhadap variabel terkait.

Untuk mengetahui seberapa besar pengaruh variabel $\mathrm{X}$ terhadap variabel $\mathrm{Y}$ dengan menggunakan koefisien determinasi $\left(\mathrm{R}^{2}\right)$ yang dinyatakan dalam presentase :

Tabel 3. Koefisien Determinasi $\left(\mathrm{R}^{2}\right)$

\begin{tabular}{|l|l|l|l|l|}
\hline Model & $\mathrm{R}$ & R Square & Adjusted R Square & $\begin{array}{l}\text { Std. Error of the } \\
\text { Estimate }\end{array}$ \\
\hline 1 & $.791^{\mathrm{a}}$ & .626 & .621 & 1.780 \\
\hline
\end{tabular}

a. Predictors: (Constant), Total Strategi Promosi

Hasilnya sebagai berikut:

$$
\begin{aligned}
\mathrm{R}^{2} & =0.626 \times 100 \% \\
& =62,6 \%
\end{aligned}
$$

Dari hasil perhitungan diatas maka dapat disimpulkan bahwa ada pengaruh variabel strategi promosi terhadap keputusan pembelian sebesar $62,6 \%$, dan sisanya dipengaruhi oleh variabel bebas lainnya.

\subsection{Uji $t$}

Uji $\mathrm{t}$ digunakan untuk mengetahui apakah variabel bebas berpengaruh secara signifikan terhadap variabel terikat. Serta untuk menguji pengaruh masing-masing variabel bebas yang digunakan dalam penelitian ini secara parsial digunakan uji t dengan tingkat signifikan sebesar $5 \%(\alpha=0,05)$.

\begin{tabular}{|c|c|c|c|c|c|c|c|}
\hline & & & \multicolumn{2}{|c|}{$\begin{array}{l}\text { Unstandardized } \\
\text { Coefficients }\end{array}$} & \multirow{2}{*}{\begin{tabular}{|l} 
Standardized \\
Coefficients
\end{tabular}} & \multirow[b]{2}{*}{$\mathrm{t}$} & \multirow[b]{2}{*}{ Sig. } \\
\hline \multicolumn{3}{|c|}{ Model } & B & Std. Error & & & \\
\hline \multirow[t]{2}{*}{1} & (Constant) & & -.922 & 3.436 & & -.268 & .789 \\
\hline & $\begin{array}{l}\text { Total } \\
\text { Promosi }\end{array}$ & Strategi & $\mathrm{i} 1.007$ & .094 & .791 & 10.679 & .000 \\
\hline
\end{tabular}

Tabel 4. Uji Signifikansi Variabel (X)

a. Dependent Variable: Total Keputusan Pembelian

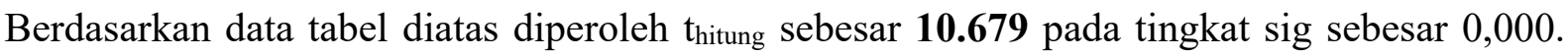
Kriteria diterimanya hipotesis:

a. Jika thitung $>\mathrm{t}_{\text {tabel }}$ dan $\mathrm{sig}<0,05$ maka $\mathrm{H}_{0}$ ditolak dan $\mathrm{H}_{1}$ diterima

b. Jika $\mathrm{t}_{\text {hitung }}<\mathrm{t}_{\text {tabel }}$ dan sig $>0,05$ maka $\mathrm{H}_{0}$ diterima dan $\mathrm{H}_{1}$ ditolak 
c. Taraf nyata $=5 \%$ drajat kebebasan $(\mathrm{df})=\mathrm{n}-2=70-2=68$

Dari hasil perhitungan diatas diketahui bahwa nilai $\operatorname{sig}(0,000>0,05)$. Hal ini berarti $\mathrm{H}_{0}$ diterima dan $\mathrm{H}_{1}$ ditolak, sehingga dapat disimpulkan bahwa strategi promosi berpengaruh positif secara signifikan terhadap keputusan pembelian.

\section{Kesimpulan dan Saran}

\subsection{Kesimpulan}

Setelah melalui berbagai macam pengujian dan analisis data, maka peneliti mencoba memberikan paparan pembahasan dengan menghubungkan antara teori-teori, penelitianpenelitian terdahulu dengan hasil penelitian yang dilakukan agar dapat memberikan suatu gambaran mengenai pembahasan ilmiah suatu penelitian, maka dapat dibuat kesimpulan sebagai berikut:

1. Dari hasil uji t diketahui bahwa strategi promosi berpengaruh secara positif dan signifikan terhadap keputusa pembelian dengan hasil yang ditujukkan dengan uji t yang memiliki nilai signifikan lebih kecil dari 0,05 yaitu sebesar 0,000 .

2. Dari hasil uji koefisien korelasi (R) diperoleh nilai sebesar 0,791 hal ini menunjukkan bahwa hubungan antara variabel Strategi Promosi (X) mempunyai hubunga yang kuat terhadap variabel Keputusan Pembelian (Y) dengan presentase sebesar 79,1\%.

3. Dari hasil uji koefisien determinasi $\left(\mathrm{R}^{2}\right)$ diperoleh nila sebesar 0,626 . Hal ini menunjukkan bahwa besarnya kontribusi variabel strategi promosi $(\mathrm{X})$ dapat menjelaskan keputusan pembelian (Y) sebesar 62,6\%, sisanya sebesar 37,4\% bisa dijelaskan oleh variabel lain yang tidak dimasukkan dalam penelitian ini.

\subsection{Saran}

Setelah melakukan penelitian dan pembahasan, maka penulis dapat memberikan beberapa saran yang berkaitan dengan penelitian yang dilakukan yaitu sebagai berikut:

1. Saran bagi Perusahaan

a. Pihak manajemen perusahaan sebaiknya lebih memperhatikan strategi-strategi yang dipakai guna peningkatan keputusan pembelian konsumen untuk produknya agar dapat memenuhi tujuannnya.

b. Strategi promosi yang baik merupakan faktor yang cukup penting dalam usaha perusahaan dalam meningkatkan keputusan pembelian konsumen untuk produknya. Dengan kata lain, perusahaan haruslah memperhatikan dan merencanakan strategi promosi serta penentuan harga jual dengan sangat hati-hati agar tidak terjadi kesalahan dalam perusahaan.

2. Bagi peneliti selanjutnya dapat menambahkan variabel lain sebagai variabel independen baik berasal dari faktor eksternal maupun internal, guna mengetahui variabel-variabel yang dapat memperkuat atau memperlemah variabel dependen.

\section{Referensi}

Arifai, A. A., \& Trihandayani, Z. (2018). HARGA, KUALITAS PRODUK DAN MEREK TERHADAP KEPUTUSAN PEMBELIAN TAS KW CARTIER DI KALANGAN MAHASISWI SEBAGAI PENUNJANG PENAMPILAN KULIAH. Jurnal Ilmiah Ekonomi Global Masa Kini, 8(3), 16-22. 
Assauri, Sofjan. 2004. Manajemen Pemasaran. Jakarta: Rajawali Press.

Basu Swasta, Dharmesta dan Irawan, (2008) Manajemen Pemasaran Modern, Liberty, Yogyakarta.

Batu, R. L., Suryani, N. I., Septia, N., \& Sekaryahya, P. F. (2020). Pengaruh Harga dan Inovasi Layanan Aplikasi terhadap Keputusan Penggunaan Jasa Taksi Express: Survei pada Pengunduh Aplikasi Express Taxis. Jurnal Nasional Manajemen Pemasaran \& SDM, 1(01), 1-22. https://doi.org/10.47747/jnmpsdm.v1i01.6

Ghozali, I, 2013. Metode Penelitian. Bandung: Pustaka Setia.

Irawan, D., Marnisah, L., \& Azrai'e, K. R. (2018). ANALISIS PRODUK DAN HARGA TERHADAP KEPUTUSAN MAHASISWA UNIVERSITAS IGM MEMBELI SMARTPHONE SAMSUNG. Jurnal Ilmiah Ekonomi Global Masa Kini, 8(2), 35-41.

Lamb, Charles. W, dkk. 2001. Pemasaran. Terjemahan oleh David Octarevia. Jakarta: Salemba Empat.

Marnisah, L., Saputra, D., \& Azra'ie, K. R. (2016). ANALISA EFEKTIFITAS PROMOSI TERHADAP KEPUTUSAN KONSUMEN PADA MEMBELI SEMEN BARURAJA DI KELURAHAN SEKIP JAYA KECAMATAN KEMUNING PALEMBANG. Jurnal ilmiah Ekonomi Global masa kini, 7(3), 16-20.

Moekijat. 2000. Kamus Manajemen, Bandung, Penerbit CV. Mandar Maju.

Nitisusastro, Mulyadi. 2012. Perilaku Konsumen. Alfabeta. Bandung. Swastha, Basu dan Irawan. 2002. Manajemen Pemasaran Modern. Penerbit liberty, Yogyakarta.

Philip Kotler, 2002, Manajemen Pemasaran, Edisi Millenium, Jilid 2, PT Prenhallindo, Jakarta

Sugiyono. (2014). Metode Penelitian Pendidikan Pendekatan Kuantitatif, Kualitatif, dan R\&D. Bandung: Alfabeta.

Sujarweni, Wiratna. 2014. Metodologi penelitian: Lengkap, praktis, dan mudah dipahami. Yogyakarta: PT Pustaka Baru

Susanti, N., Halin, H., \& Kurniawan, M. (2018). PENGARUH BAURAN PEMASARAN (4P) TERHADAP KEPUTUSANPEMBELIAN PERUMAHAN PT. BERLIAN BERSAUDARA PROPERTINDO (Studi Kasus Perumahan Taman Arizona 1 Taman Arizona 2 dan Taman Arizona 3 di Talang Jambi Palembang). Jurnal Ilmiah Ekonomi Global Masa Kini, 8(1), 43-49.

Tjiptono, F. 2001. Manajemen pemasaran dan analisa perilaku konsumen.

Wadud, M. (2018). BAURAN PEMASARAN JASA (3 Ps: PEOPLE, PROCESS \& PHYSICAL EVIDENCE) BAGI KEPUASAN PELANGGAN. Jurnal Ilmiah Ekonomi Global Masa Kini, 8(1), 21-29.

Wahid, R. M., \& Wadud, M. SOCIAL MEDIA MARKETING ON INSTAGRAM: WHEN IS THE MOST EFFECTIVE POSTING TIMING?. 